Kamil Niewiński

Uniwersytetu w Białymstoku

e-mail: kamilnwski@gmail.com

\title{
Dokumenty archiwalne dotyczące oceny sytuacji społeczno-politycznej w środowiskach prawniczych, stanowiące materiał informacyjny na posiedzenie Biura Politycznego KC PZPR z dnia 28 lutego 1984 roku
}

\begin{abstract}
SUMMARY
An Archive Document about the Assessment of the Social and Political Situation among Lawyers, Prepared for the Political Bureau in February 1984

The presented document was included among informational materials for a session of the Political Bureau of the Central Committee of the Polish United Workers' Party (KC PZPR) on February 28, 1984. It was a report drafted by the Administrative Department of the Central Committee of PZPR, discussing both the social and political situation in lawyers' circles. This topic was high on the agenda of political debates among communist party decision-makers, due to the strong influence the 'Solidarność' movement had on lawyer's circles. Since the introduction of martial law on December 13,1981, the communist party was trying to withdraw licences to practice a profession for all judges, prosecutors, attorneys and legal counsels who supported 'Solidarność. For this reason, the Administrative Department of the Central Committee of PZPR kept a close watch on the lawyers' circles.
\end{abstract}

Key words: lawyers' circles, Political Bureau, advocates, Solidarity 


\section{Wprowadzenie}

Prezentowany dokument przedstawia sporządzoną przez Wydział Administracyjny KC PZPR ocenę sytuacji kadrowej w środowisku prawniczym w Polsce Ludowej u progu $1984 \mathrm{r}$.

W grudniu 1983 r. Biuro Polityczne KC PZPR zleciło Komisji Prawa i Praworządności, wchodzącej w skład Wydziału Administracyjnego KC, sporządzenie „oceny podejmowanych działań na rzecz dalszej poprawy pracy organów ścigania i wymiaru sprawiedliwości, w tym także istniejącej sytuacji kadrowej w tych organach". Osobami odpowiedzialnymi za stworzenie niniejszego dokumentu byli: minister spraw wewnętrznych Czesław Kiszczak, prokurator generalny Franciszek Rusek, minister sprawiedliwości Lech Domeracki oraz I Prezes Sądu Najwyższego Włodzimierz Berutowicz.

Sporządzona przez Wydział Administracyjny ocena została, z polecenia kierownika wydziału Mirosława Milewskiego, przesłana 20 lutego 1984 r. członkom Biura Politycznego, ich zastępcom oraz sekretarzom. Stanowiła materiał informacyjny, przygotowany na drugą część posiedzenia Biura Politycznego w dniu 28 lutego 1984 r. W drugim punkcie porządku dziennego niniejszego posiedzenia przewidziano dyskusję nad przedmiotową oceną. Stanowiła ona część szerzej dyskutowanego tematu, związanego z problematyką przestrzegania prawa i umacniania praworządności w kraju po wprowadzeniu stanu wojennego.

Dokument niniejszy składa się z części sprawozdawczej oraz konkluzji. W części sprawozdawczej autorzy przedstawili sytuację kadrową, ze szczególnym wskazaniem zjawisk stanowiących zagrożenie dla prawidłowego, to jest zgodnego z linią polityczną partii, funkcjonowania:

I - sądów rejonowych, sądów wojewódzkich i prokuratury,

II - Sądu Najwyższego,

III - Naczelnego Sądu Administracyjnego,

IV - Państwowego Arbitrażu Gospodarczego,

V - adwokatury,

VI - środowiska radców prawnych.

Niezwykle ważnym mechanizmem zapewniającym realizację polityki partii w wymiarze sprawiedliwości było bowiem utrzymanie wysokiego poziomu upartyjnienia kadry sądowo-prokuratorskiej. Zabezpieczała ona dyspozycyjność sędziów i prokuratorów, oddanych idei socjalistycznej i związanych dyscypliną partyjną. Po wydarzeniach z sierpnia 1980 r., coraz większy wpływ na środowisko prawnicze zyskiwała NSZZ „Solidarność. Jak podaje Andrzej Rzepliński, do związków zawodowych niepodporządkowanych partii należało wówczas oko- 
ło 28\% sędziów (autorzy oceny podają, iż w 1981 r. do "Solidarności” należała 1/4 sędziów). Dane te potwierdza informacja, którą przygotował Wydział Administracyjny KC PZPR, sporządzona 2 marca 1981 r. Na ogólną liczbę 3776 sędziów i asesorów zatrudnionych w resorcie sprawiedliwości, do „Solidarności” przystąpiło 978 osób, czyli około 27\% zatrudnionych. Równolegle spadała liczba sędziów z legitymacjami partyjnymi. W 1979 r. do PZPR w sądach rejonowych należało 56,9\% kadry, a w sądach wojewódzkich - 69,3\%, największe wpływy partia miała w Sądzie Najwyższym - 77,8\%. Brak jest informacji dotyczących stopnia upartyjnienia sądownictwa w latach 1980-1981. Przybliżonej liczby sędziów należących do partii, którzy wstąpili do NSZZ „Solidarność” Pracowników Wymiaru Sprawiedliwości, nie były w stanie określić nawet osoby z kierownictwa związku. Robert Walczak podaje, iż już w 1980 r. do „Solidarności” przystąpiło 295 członków PZPR, w większości byli to sędziowie sądów rejonowych. Ruch związkowy nie znalazł jednak uznania w Sądzie Najwyższym. Z przeprowadzonej przez J. Strzelecką rozmowy z przewodniczącym Komisji NSZZ „Solidarność" w Ministerstwie Sprawiedliwości, sędzią Sądu Wojewódzkiego Adamem Strzemboszem, dowiadujemy się, iż w na najwyższym szczeblu sądownictwa do ruchu związkowego przystąpiło zaledwie kilku sędziów, z czego część stanowili sędziowie emerytowani. Poza tym, wielu sędziów oddało legitymacje partyjne nie wchodząc do związków zawodowych, na co zwracali uwagę autorzy prezentowanego dokumentu, wskazując jednocześnie, iż pozostawienie tych osób $\mathrm{w}$ gronie aktywnych pracowników wymiaru sprawiedliwości było niefortunnym przeoczeniem.

W okresie stanu wojennego partia podjęła działania w celu wyeliminowania niepokornych sędziów. Nie przyniosły one jednak skutku na najniższym szczeblu sądownictwa. Jak podają autorzy oceny, na koniec 1983 r. do PZPR należało ogółem 55,6\% sędziów (nie wliczając w to sędziów Sądu Najwyższego), z czego w sądach wojewódzkich stanowili oni $68,2 \%$ kadry. Wynika stąd, iż drastycznie spadła liczba sędziów partyjnych w sądach rejonowych (do 43\%). Główny nurt opozycyjny objął więc najniższy szczebel sądownictwa; w sądach wojewódzkich i Sądzie Najwyższym, w którym do partii należało 78,1\% kadry, pozycja PZPR była praktycznie niezachwiana. Pamiętać jednak należy, iż prezentowany procentowy raport stopnia upartyjnienia kadr sądowych w stosunku do analogicznych danych z roku 1979 r. był zdeformowany, ze względu na problem masowej rezygnacji sędziów z piastowanej godności i powiększającej się liczby wacatów w sądownictwie (w niektórych województwach sięgający nawet 25\%).

Kadry prokuratury pozostały wierne władzy ludowej. Do związku pod egidą „Solidarności” przystąpiła niewielka ilość prokuratorów. Jednak, podobnie jak w sądownictwie, borykała się ona z niedoborem pracowników.

Bastionem opozycji wobec władzy w okresie posierpniowym stała się adwokatura. Choć formalnie w uchwale Ogólnopolskiego Zjazdu Adwokatów 
w Poznaniu z 4 stycznia 1981 r. zapisano, iż adwokatura stała na gruncie zasad ustroju socjalistycznego wyrażonych w Konstytucji PRL, to jej postulaty zdecydowanie dążyły ku demokratyzacji życia w kraju i pozbawienia partii kontroli nad organami władzy państwowej, w szczególności nad wymiarem sprawiedliwości. Co ciekawe, również adwokaci związani z PZPR widzieli potrzebę reform, czego wyrazem był referat wygłoszony 14 kwietnia $1981 \mathrm{r}$. na zebraniu Podstawowej Organizacji Partyjnej przy Radzie Adwokackiej w Warszawie. Pomimo podejmowanych przez partię prób odzyskania kontroli nad adwokaturą, jej inwigilacją i podejmowaniem działań destrukcyjnych, a nawet spełnieniem postulatu reformy jej ustroju, środowisko adwokackie trwało w opozycji wobec władzy. Świadczą o tym obrady I Krajowego Zjazdu Adwokatury w dniach 1 - 2 października $1983 \mathrm{r}$. oraz dokumenty partyjne relacjonujące te wydarzenia i piętnujące antysocjalistyczne wystąpienia adwokatów.

Odzyskanie kontroli nad niepokornym środowiskiem prawniczym było jednym z naczelnych zadań PZPR. Stąd też, w konkluzji prezentowanego dokumentu Wydział Administracyjny wskazał, w 10 punktach, konkretne działania zmierzające do podporządkowania wymiaru sprawiedliwości. Ich wykonawcami miały być nie tylko instancje partyjne. Adresatami zaleceń Wydziału Administracyjnego KC PZPR były także Sejm, Rada Państwa, Ministerstwo Sprawiedliwości, Ministerstwo Nauki, Szkolnictwa Wyższego i Techniki oraz organy i środowiska będące przedmiotem oceny. Zwraca uwagę fakt, iż wydana na podstawie prezentowanego materiału informacyjnego decyzja Biura Politycznego z 28 lutego 1984 r., powiela 9 punktów z konkluzji opracowanej przez Wydział Administracyjny i zaleca ich realizację. Biuro Polityczne odrzuciło jedynie propozycję podwyżek płac dla prokuratorów i sędziów.

W niniejszym przypadku uwidacznia się nie tylko stosunek PZPR do środowiska prawniczego, ale również mechanizm sprawowania przez partię roli przewodniej siły w budowie socjalizmu. Sporządzona przez Wydział Administracyjny KC PZPR ocena sytuacji kadrowej, stała się przedmiotem dyskusji Biura Politycznego. Wytyczne zawarte w decyzji Biura Politycznego wyznaczyły zaś konkretne kierunki działania, które miały realizować organy państwowe. Zmierzały one do zabezpieczenie wrażonych w Konstytucji PRL zasad ustroju socjalistycznego, a w szczególności przewodniej, czy też kierowniczej roli PZPR, w tym przypadku w środowisku prawniczym i w zakresie wymiaru sprawiedliwości. 


\section{Dokument}

1984 luty, Warszawa. - Dokument sporzadzony przez Wydział Administracyjny KC PZPR, stanowiacy materiał informacyjny na posiedzeniu Biura Politycznego

KC PZPR z dnia 28 lutego $1984 r{ }^{1}$

Tajne

Egz. $\mathrm{nr} 29^{2}$

\section{Ocena sytuacji społeczno-politycznej w środowisku prawniczym ${ }^{3}$}

Środowisko prawnicze w Polsce liczy obecnie 59.993 osoby z wykształceniem prawniczym / nie uwzględniono w tej liczbie prawników zatrudnionych w $\mathrm{MSW}^{4}$, $\mathrm{MON}^{5}$ oraz aparacie organizacji politycznych i społecznych/. $\mathrm{Z}$ tej liczby 38.627 osób pracuje w sektorze uspołecznionym, spośród których zawody prawnicze wykonuje 28.049 osób; w administracji państwowej zatrudnionych jest 9.294 prawników. Istotne znaczenie ma fakt, że jest to środowisko ludzi wykształconych, tkwiących w różnych dziedzinach naszego życia społecznego, politycznego i gospodarczego, cieszące się autorytetem w społeczeństwie, o dużej sile opiniotwórczej. ${ }^{6}$

Rolę prawników wyznacza także ranga, jaką nadał prawu IX Nadzwyczajny Zjazd PZPR w swych uchwałach, upatrując w nim gwaranta procesu socjalistycznej odnowy i prawnych podstaw reformy gospodarczej. Dla podkreślenia roli, którą przywiązuje kierownictwo partii do środowiska prawniczego, Biuro Polityczne poświęciło tej sprawie swoje posiedzenie w marcu 1982 r. a I Sekretarz KC przyjął przedstawicieli $\mathrm{ZPP}^{7} \mathrm{w}$ dniu 8 czerwca $1983 \mathrm{r}$.

Niedostateczny jest wciąż współudział prawników w kształtowaniu kierunków polityki społecznej i gospodarczej państwa poprzez uczestnictwo w działalności legislacyjnej oraz precyzyjnym, zgodnym z interesami politycznymi poprawnym formułowaniu aktów prawnych.

Wciąż za mała jest rola środowiska w wysuwaniu, a szczególnie konsekwentnym wcielaniu w życie inicjatyw służących umacnianiu państwa i po-

1 W publikacji zachowana została oryginalna treść dokumentu. Dlatego też, mogą wystąpić błędy literowe, stylistyczne itp.

2 Z lewej strony pieczęć: Materiał informacyjny.

3 Powyżej z prawej strony pieczęć uzupełniona odręcznie: $z$ polecenia tow. M. Milewskiego wysłano Członkom BP, Z-com, Sekretarzom dnia 20.II.1984 r. L. dz. Ks/032/399/84.

Ministerstwo Spraw Wewnętrznych.

5 Ministerstwo Obrony Narodowej.

6 Pod niniejszym fragmentem tekstu pieczęć: Na posiedzenie BP $w$ dn. 28.II.1984 r.

7 Zrzeszenie Prawników Polskich - ogólnopolskie stowarzyszenie prawników, osób wykonujących zawody prawnicze, a także studentów prawa, założone w $1945 \mathrm{r}$. 
rządku prawnego, poszanowania dla prawa i ideowych wartości socjalizmu. Prawnicy mają duże możliwości odegrania poważnej roli w zbliżającej się kampanii wyborczej do rad narodowych.

Prawnicy powinni znaleźć się w pierwszym szeregu sił społeczeństwa polskiego przeciwstawiających się wszelkim przejawom wrogiej działalności wymierzonej przeciwko socjalistycznemu porządkowi prawnemu w naszym kraju oraz aktywnie uczestniczyć w toczącej się walce politycznej.

I. Szczególna rola w ochronie politycznych i ekonomicznych interesów socjalistycznego państwa oraz zapewnieniu ładu i porządku w kraju przypada prawnikom zatrudnionym $w$ organach ścigania i wymiaru sprawiedliwości.

Podstawowa kadra resortu sprawiedliwości liczy 4.572 osoby, w tym 885 sędziów wojewódzkich, 2.312 sędziów rejonowych, 652 asesorów sądowych, 192 sędziów pracy i ubezpieczeń społecznych, 475 notariuszy i 56 asesorów notarialnych. Wysoki jest stopień upartyjnienia kadry

\section{- 2 -}

sędziowskiej - $2 / 3$ jej stanu należy do partii i stronnictw politycznych, w tym 55,6\% jest członkami PZPR /w sądach wojewódzkich 68,2\%/,2,6\% - ZSL ${ }^{8}, 4,7 \%$ - SD $\%$. Szereg sędziów pełni odpowiedzialne funkcje polityczne i społeczne. M.in. 11 sędziów jest członkami KW ${ }^{10}, 1$ z-cą członka KW, 7 - członkami WKKP ${ }^{11}, 5$ - WKR ${ }^{12}$, a 37 członkami i zastępcami członków komitetów miejskich i miejsko-gminnych PZPR, 20 - członkami MKKP ${ }^{13}$ i 11 - członkami MKR ${ }^{14}$; 31 sędziów wybrano dotychczas członkami komisji problemowych komitetów partyjnych. Jedenastu sędziów urlopowano do pracy $\mathrm{w}$ aparacie partyjnym. Ponadto 24 sędziów jest radnymi wojewódzkimi, a 93 - radnymi miejskimi rad narodowych. Sędziowie stanowią 1/3 składu ZG ZPP.

W jednostkach prokuratury zatrudnionych jest 3.018 prokuratorów i 650 aplikantów oraz 2.050 pracowników administracyjnych i 1.132 pracowników obsługi. Wyrazem ideowym postaw prokuratorów jest wysoki stopień ich upartyjnienia wynoszący $75,2 \%$ oraz ich zaangażowanie w pracy politycznej, pełnienie odpowiedzialnych funkcji w instancjach partyjnych, radach narodowych i organizacjach społecznych. M.in. dwaj prokuratorzy są

8 Zjednoczone Stronnictwo Ludowe - partia polityczna, powstała 27 listopada 1949 r. z połączenia „lubelskiego” Stronnictwa Ludowego z resztkami rozbitego przez komunistów PSL „mikołajczykowskiego". ZSL było partią satelicką PZPR, zrzeszoną we Froncie Jedności Narodu.

9 Stronnictwo Demokratyczne - polska centrowa partia polityczna założona 15 kwietnia 1939. W okresie drugiej wojny światowej działała w ramach Polski Walczącej. W okresie Polskiej Rzeczypospolitej Ludowej partia sojusznicza wobec PZPR, zrzeszona we Froncie Jedności Narodu.

10 Komitety Wojewódzkie PZPR.

11 Wojewódzka Komisja Kontroli Partyjnej KW PZPR.

12 Wojewódzka Komisja Rewizyjna KW PZPR.

13 Miejska Komisja Kontroli Partyjnej KM PZPR.

14 Miejska Komisja Rewizyjna KM PZPR. 
członkami CKKP ${ }^{15}, 42$ - członkami KW, 164 - członkami komitetów szczebla podstawowego, 66 - członkami komisji problemowych komitetów partyjnych, 170 - lektorami KW PZPR, a 8 - lektorami KC PZPR. Do pracy w aparacie partyjnym urlopowanych zostało 21 prokuratorów. Ponadto 31 prokuratorów jest radnymi wojewódzkich rad narodowych, a 121 - radnymi rad narodowych stopnia podstawowego. O wysokiej aktywności prokuratorów w Zrzeszeniu Prawników Polskich świadczy fakt, że 21 z nich pełni funkcje prezesów zarządów wojewódzkich ZPP. Wielu prokuratorów podjęło działalność w PRON ${ }^{16}$.

W polityce kadrowej sporą wagę starano się przywiązywać do kształtowania zaangażowanych postaw oraz do poprawy systemu naboru, szkolenia i doskonalenia prokuratorów i sędziów, jak również tworzenia rezerwy kadry kierowniczej.

W Prokuraturze Generalnej i Ministerstwie Sprawiedliwości i w zasadzie realizowane są kompleksowe programy szkolenia

oraz zawodowego i ideowo-politycznego doskonalenia kadry - zgodnie z zaleceniami Biura Politycznego. Celem lepszego doboru ludzi do zawo$\mathrm{du}$ prokuratorskiego i sędziowskiego, nawiązane zostało systematyczne współdziałanie z dziekanami wydziałów prawa. W prokuraturze w 1982 r. wprowadzono istotne zmiany $\mathrm{w}$ systemie szkolenia aplikantów. Zorganizowano 17 ośrodków międzywojewódzkich, których kierownikami mianowano najbardziej doświadczonych zawodowo i politycznie prokuratorów. Obok tematyki zawodowej realizowany jest program wychowania ideowo-politycznego, często z udziałem członków instancji partyjnych i weteranów ruchu robotniczego. Aplikanci odbywający szkolenie także w sądach, arbitrażu i w $\mathrm{MO}^{17}$.

Corocznie przeprowadzana jest ocena kadry resortowej. Np. w wyni$\mathrm{ku}$ ostatniego przeglądu kadrowego w resorcie sprawiedliwości odwołano 7 prezesów sądów wojewódzkich oraz okręgowych sądów pracy i ubezpieczeń społecznych, $\mathrm{w}$ związku z niezadowalającymi efektami pracy zawodowej.

W środowisku sędziowskim i prokuratorskim występuje szereg negatywnych zjawisk, którym energiczne przeciwdziałanie jest pilną koniecznością. Problemem staje się odchodzenie z pracy sędziów i - zwłaszcza prokuratorów do innych zawodów prawniczych. W 1983 r. zrezygnowało

15 Centralna Komisja Kontroli Partyjnej KC PZPR.

16 Patriotyczny Ruch Odrodzenia Narodowego - organizacja polityczna (początkowo pod nazwą Obywatelskie Komitety Ocalenia Narodowego) utworzona w okresie stanu wojennego przez PZPR i podporządkowane jej stronnictwa polityczne ZSL i SD oraz zależne od władz organizacje katolickie, w celu propagandowego wykazania poparcia społeczeństwa dla polityki partii, a w szczególności wprowadzenia stanu wojennego. PRON nawiązywał do tradycji działalności Frontu Jedności Narodu.

17 Milicja Obywatelska. 
z pracy w sądownictwie 159 sędziów i notariuszy; w latach poprzednich zwalniało się przeciętnie 52 sędziów rocznie. Natomiast w okresie od 1 stycznia 1980 r. zwolniło się ze służby 506 prokuratorów i obecnie pozostaje nieobsadzonych 531, tj. 15,4\% stanowisk prokuratorskich. W wielu rejonach kraju wskaźnik procentowy wacatów jest znacznie wyższy: w województwach warszawskim, gdańskim i szczecińskim wynosi około $25 \%$, natomiast w województwie katowickim i w Prokuraturze Generalnej-20\%. W licznych prokuraturach rejonowych stan zatrudnienia kształtuje się już poniżej dopuszczalnego minimum.

Większość rezygnujących z pracy sędziów i prokuratorów to ludzie w wieku pomiędzy 30 a 40 rokiem życia, z kilkunastoletnim stażem, o wysokich kwalifikacjach zawodowych i optymalnie przydatni.

Można przyjąć, że głównymi przyczynami tego stanu jest nienormowany czas pracy wynikający z przeciążenia sprawami, niepopularność zwodu /zwłaszcza prokuratorskiego/, a także braki w ideologicznym przygotowaniu kadry w czasie studiów.

Nie bez znaczenia jest także poziom płac. Z dokonanych ustaleń wynika, że zarobki prokuratorów i sędziów o krótkim a nawet średnim stażu są znacznie niższe od wynagrodzeń uzyskiwanych np. przez radców prawnych, a także od zarobków wielu grup zawodowych, w których nie jest wymagane posiadanie wyższego wykształcenia i wiadomości specjalistycznych. Zjawisko to jest tym bardziej charakterystyczne, że przygotowanie do wykonywania czynności prokuratora i sędziego trwa 8 lat /5 lat studiów oraz 3 lata aplikacji i asesury /.

Trudna jest również sytuacja mieszkaniowa w tym resorcie. Np. na tle obowiązujących zasad przydziału mieszkań prokuratura i resort sprawiedliwości nie posiadają żadnych możliwości uzyskania lokali mieszkalnych dla swych pracowników.

Wymienione zjawiska nie wyczerpują zakresu trudności występujących w sądownictwie i prokuraturze.

W okresie pomiędzy sierpniem 1980 r. a grudniem 1980 r. działalność organów ochrony porządku prawnego w stopniu istotnym była utrudniona na skutek zarówno powszechnego braku poszanowania prawa, jak i utrudniania czy wręcz uniemożliwiania ścigania sprawców ich naruszeń. Anarchizujące działania opozycji politycznej i mało skuteczne przeciwdziałanie kierownictwa resortu sprawiedliwości doprowadziły w 1981 r. do głębokich podziałów środowiska sędziowskiego / do b. NSZZ „Solidarność"18 należała 1/4 kadry sędziowskiej/, dezorganizacji pracy sądownictwa a nawet do załamania polityki karnej. W sądach powszechnych wystąpiła wyraźna tendencja do nadmiernej liberalizacji polityki karnej i obniżania wysokości kar do

18 Niezależny Samorządny Związek Zawodowy „Solidarność”. 
najniższych granic ustawowego zagrożenia, wzrostu liczby warunkowych zawieszeń przy jednoczesnym niepełnym wykorzystaniu katalogu środków karnych o charakterze nieizolacyjnym. Sytuacja ta stwarzała ryzyko załamania ochronnej funkcji prawa i podważania zasad porządku prawnego.

- 5 -

Po wprowadzeniu stanu wojennego, w wyniku dokonanego przeglądu kadrowego Rada Państwa odwołała 25 oraz przyjęła rezygnację z pracy 11 sędziów. Ze służby w prokuraturze w pierwszych tygodniach stanu wojennego zwolniono 15 prokuratorów i 2 aplikantów oraz przyjęto rezygnację z pracy kolejnych 15 prokuratorów.

Podjęte $\mathrm{w}$ resorcie sprawiedliwości bezpośrednio po wprowadzeniu stanu wojennego przedsięwzięcia polityczne, dyscyplinujące i kadrowe doprowadziły do wyeliminowania działań ekstremalnych i poważnego zneutralizowania jawnych postaw destrukcyjnych. W 1982 r. wypracowano i wdrożono nowy model nadzoru sądowego mający na celu skuteczniejszą kontrolę nad orzecznictwem i sprawnością postępowania sądowego, zorganizowano i uruchomiono system cyklicznego szkolenia ideologicznego i fachowego, opracowano projekt zmian ustawodawczych dotyczących struktury organizacyjnej sądownictwa powszechnego. Działania te spowodowały, że kadra sędziowska generalnie zrealizowała zadania określone po wprowadzeniu stanu wojennego. W 1984 r. w sądownictwie stwierdza się postępującą stabilizację i wyciszanie okazywanych w przeszłości przejawów sympatii i poparcia dla haseł opozycji. Tym niemniej nie zostały zlikwidowane wszystkie negatywne zjawiska społeczno-polityczne, o czym świadczyć mogą fakty np. demonstracyjnego klerykalizmu, wyrażania sympatii dla poczynań podziemia oraz towarzyskiego i zawodowego bojkotu sędziów prezentujących właściwe postawy. Słaba jest aktywność organizacji partyjnych w sądownictwie wyrażająca się m.in. nie podejmowaniem działań zabezpieczających należyte wykonywanie przez sądy zadań w zakresie ochrony prawnej interesów państwa socjalistycznego. Wymownym jest fakt, że po wprowadzeniu stanu wojennego 14 sędziów zostało wydalonych z partii, a 68 oddało legitymacje partyjne z motywów politycznych; przeważająca część nich nadal wykonuje zawód. Niezadowalający jest także udział środowiska sędziowskiego w pracach PRON.

\section{- 6 -}

Wywierana jest również, nierzadko skuteczna, presja na sędziów rozpoznających sprawy o charakterze politycznym, której efektem są niewłaściwe, błędne orzeczenia, zwłaszcza z zakresu prawa karnego i prawa pracy /w tym przypadku zdecydowana większość kwestionowanych decyzji podejmowana jest przez terenowe komisje odwoławcze, które nie podlegają Ministerstwu Sprawiedliwości/.

Szczególnie negatywnie z moralnego punktu widzenia ocenić należy fakty bezprawnego podziału wśród pracowników Sądu Rejonowego 
w Lublinie darów przeznaczonych dla wychowanków zakładu poprawczego oraz nieprawidłowości i nadużycia z bonami obiadowymi w Sądzie Wojewódzkim w Zamościu.

Największe nasilenie negatywnych zjawisk społeczno-politycznych, determinujących również orzecznictwo sądowe występuje w Warszawie oraz w województwach szczecińskim, katowickim, gdańskim i bydgoskim.

Działania opozycji, która od 1980 r. wytworzyła wręcz wrogą atmosferę wokół prokuratury, a nawet zastraszała niektórych jej pracowników, doprowadziły do przypadków ulegania i politycznej dezorientacji pewnej części, zwłaszcza młodych prokuratorów. W zdecydowanej większości kadra prokuratorska wykazała ideowość, dojrzałość polityczna, dyspozycyjność i odporność psychiczną. Jednak w pięciu jednostkach organizacyjnych prokuratury powstały koła NSZZ „Solidarność”, ukonstytuował się Krajowy Komitet Pracowników Prokuratury NSZZ "Solidarność”, niektórzy prokuratorzy aktywnie uczestniczyli w kampaniach propagandowych tego związku. Przedsięwzięcia dyscyplinująco-weryfikacyjne po wprowadzeniu stanu wojennego przyczyniły się do ustabilizowania sytuacji społeczno-politycznej w prokuraturze.

\section{- 7 -}

Nie bez wpływu na ten stan pozostaje poziom edukacji politycznej wyniesiony przez młodych sędziów i prokuratorów z wyższych uczelni, gdzie zwłaszcza w latach 1978-1981 panował niedowład ideowy i prowadzono niemal jawną działalność antysocjalistyczną. Niekorzystny klimat społeczno-polityczny wśród sędziów, podobnie jak w innych środowiskach prawniczych, kształtowany był również w znacznej mierze postawą i działalnością kadry naukowej PAN ${ }^{19}$. Celowym jest wzmożenie oddziaływania polityczno-administracyjnego na środowiska dla zneutralizowania negatywnych tendencji. Sytuacja na uniwersyteckich wydziałach prawa i w Polskiej Akademii Nauk wymaga odrębnej analizy, którą powinny dokonać Wydział Nauki i Oświaty KC PZPR oraz Ministerstwo Nauki, Szkolnictwa Wyższego i Techniki.

Krytycznie ocenić należy sprawność postępowania przygotowawczego i sądowego. W wyniku m.in. zwiększonego wpływu spraw do prokuratur, szybkość postępowania przygotowawczego uległa pogorszeniu i często odbiega od wymogów ustawowych. Liczba spraw pozostających do załatwienia wzrosła na koniec I półrocza ubr. O 10.723; o około 4\% zmniejszył się odsetek spraw załatwionych w okresie 1 miesiąca i zwiększyła się liczba postępowań przygotowawczych długotrwających /118 postępowań trwa powyżej 1 roku/. Przyczyną tej przewlekłości są również trudności kadrowe, jak i wadliwe ukierunkowanie czynności prokuratorskich, zwłaszcza we wstępnej fazie postępowania oraz nienależyta koncentracja i poziom tych czynności w toku dalszego postępowania.

19 Polska Akademia Nauk. 
W I półroczu 1983 r. znacznie zwiększyło się obciążenie sędziów. Do sądów wpłynęło 862.558 spraw wobec 798.670 w analogicznym okresie ub.r. Średnio miesięczne obciążenie sędziego wzrosło z 33 spraw w 1981 r. do 39 w 1983 r. Mimo wzrostu intensywności pracy zwiększyła się ilość nierozpoznanych spraw sądowych. W końcu I półrocza ub. r. Oczekiwało na załatwienie prawie 297 tys. spraw, tj. o 25,2\% więcej niż w analogicznym okresie ub.r., co stanowi blisko dwumiesięczny wpływ. Największe zaległości występują $\mathrm{w}$ sądach wojewódzkich $\mathrm{w}$ Bydgoszczy /4,9 miesięcznego wpływu/, Gdańsku /4,8/ i w Warszawie /3,3/.

Wzrastające zadania i trudności kadrowe powodują, że problematyka organizacji pracy, optymalnego wykorzystania kadry i kontroli wykonawstwa zadań w sądach i prokuraturach nabiera szczególnego znaczenia. W tym zakresie dokonano pewnego postępu, ale jest on niewystarczający w stosunku do potrzeb, a ponadto wystąpiły pewne zjawiska niekorzystne, które osłabiają efektywność działań resortu sprawiedliwości i prokuratury.

Takimi niekorzystnymi zjawiskami w resorcie sprawiedliwości są m.in. zbyt częste zmiany struktur organizacyjnych, przejmowanie-bez odpowiedniego zaplecza także kadrowego - coraz to nowych kompetencji oraz zaniedbywanie podstawowego odcinka - funkcjonowania sądów wojewódzkich i rejonowych. $\mathrm{W}$ ostatnim czasie podjęte zostały działania na rzecz wyeliminowania tych niedostatków.

W prokuraturach, zwłaszcza w niniejszych jednostkach istnieje nadmiar stanowisk funkcyjnych; ich dalsze ograniczenie jest pilną potrzebą. Są jednostki, w których połowę kadry stanowią pracownicy funkcyjni; w Prokuraturze Generalnej jest nadmiar ludzi na stanowiskach wicedyrektorów departamentów. Zgłaszane są uwagi o potrzebie zwiększenia samodzielności i sprawności prokuratorów Prokuratury Generalnej, m.in. poprzez ograniczenie wieloszczeblowego, zespołowego systemu ustalania decyzji, nadmiernie absorbującego czas prokuratorów.

II. Spośród 114 sędziów Sądu Najwyższego, 89 /78,1\%/ jest członkami PZPR, 5 - SD, 6 - ZSL.

Po sierpniu 1980 r. w Sądzie Najwyższym działały dwa związki zawodowe: Związek Pracowników Państwowych i Społecznych, skupiających

dominującą większość kadry sędziowskiej i administracyjnej oraz NSZZ "Solidarność", do którego przystąpiło 67 osób, w tym 2 sędziów Sądu Najwyższego i 1 sędzia sądu wojewódzkiego, delegowany do Biura Orzecznictwa.

Komisja Zakładowa NSZZ „Solidarność" nie odegrała w Sądzie Najwyższym poważniejszej roli, gdyż w płaszczyźnie związkowej była ona niemal 
żadna, a w pozostałym zakresie nie miała wpływu na merytoryczną pracę Sądu i sprowadzała się tylko do propagandy.

Po wprowadzeniu stanu wojennego z wszystkimi członkami NSZZ "Solidarność" przeprowadzono rozmowy. Celem tych rozmów było dokonanie oceny postaw i poglądów członków "Solidarności”, a zwłaszcza ich stosunku do uchwał powziętych w Radomiu i Gdańsku. Z trzema pracownikami administracyjnymi, którzy nie odcięli się od ekstremalnej, antypaństwowej działalności rozwiązano stosunek pracy, jednego sędziego SN odwołano ze stanowiska, a jednemu sędziemu /sądu wojewódzkiego/ cofnięto delegację do Biura Orzecznictwa.

Sąd Najwyższy jako naczelny organ sądowy sprawuje konstytucyjny nadzór nad działalnością orzeczniczą wszystkich sądów, a więc nad najważniejszą z punktu widzenia praworządności formą stosowania i rozumienia prawa. W szczególnie trudnych i złożonych warunkach społeczno-politycznych Sąd Najwyższy właściwie spełniał swą konstytucyjną rolę kontynuując ustabilizowaną linię orzecznictwa. Np. decyzje Sądu Najwyższego w sprawie przeciwko kierownictwu KPN ${ }^{20}$ udaremniły próby storpedowania tego procesu prowadzonego w sądzie warszawskim w sposób urągający powadze sądu pozwalający oskarżonym na prowadzenie na sali rozpraw agitacji antysocjalistycznej.

Istotna była rola Sądu Najwyższego po wprowadzeniu stanu wojennego. Podejmując szereg uchwał dotyczących wykładni nowego ustawodawstwa i korygując wadliwe orzeczenia sądowe, Sąd Najwyższy zapobiegał rozbieżnościom w rozumieniu i stosowaniu poszczególnych przepisów szczególnych regulacji w zakresie prawa karnego, a także w praktyce orzeczniczej sądów pracy i ubezpieczeń społecznych, zwłaszcza na tle rozwiązywania umów o pracę, zwalniania ze służby w zakładach zmilitaryzowanych.

- 10 -

W ten sposób Sąd Najwyższy ujednolicał orzecznictwo, ukierunkowując politykę stosowania prawa na realizację celów i założeń ustawodawstwa stanu wojennego. W szczególności Sąd Najwyższy korygował wiele wadliwych orzeczeń sądów powszechnych, praktykę licznych odstępowań od trybu doraźnego, przypadki uniewinnień w następstwie wadliwej interpretacji prawa, nadmierną częstotliwość przeprowadzanych badań psychiatrycznych a niejednokrotnie nieuzasadniony liberalizm. Np. Izba Karna w sprawach politycznych rozpoznawanych w trybie rewizji nadzwyczajnych zaostrzyła karę 29,9\% skazanym, w stosunku do 34,3\% uchyliła wyroki / głównej mierze uniewinniające/ $\mathrm{z}$ przekazaniem spraw do ponownego rozpoznania. W sprawach kryminalnych, rozpoznawanych w drodze rewizji nadzwyczajnych, zaostrzono 60,9\%, a złagodzono 10,9\% kar, natomiast z rewizji zwykłych wskaźnik zaostrzeń wynosił $10 \%$ a złagodzeń - 27,9\%.

20 Konfederacja Polski Niepodległej - polska partia polityczna, założona 1 września 1979 przez Leszka Moczulskiego, nawiązująca do tradycji piłsudczykowskich. 
Działalność interpretacyjna Sądu Najwyższego szeroka była również w 1983 r. w związku z zawieszeniem, a następnie zniesieniem stanu wojennego. Działania pozajudykacyjne były aktywne w związku z uchwaleniem i wdrażaniem ustawy o amnestii, ustawy o związkach zawodowych oraz kompleksu regulacji dotyczących reform społeczno-gospodarczych. Istotne znaczenie dla kształtowania właściwej polityki karnej mają uchwalone wytyczne dotyczące określenia pojęć: „korzyść majątkowa w wielkich rozmiarach", oraz „poważna szkoda" i „wielka szkoda”.

III. W Naczelnym Sądzie Administracyjnym pracuje 61 sędziów, z czego 25 w NSA w Warszawie, a 36 w 6 ośrodkach zamiejscowych /Gdańsk, Katowice, Kraków, Lublin, Poznań, Wrocław/. Kadra sędziowska rekrutuje się spośród pracowników z dużym doświadczeniem zawodowym /ustawa wymaga co najmniej 10-letniej praktyki na samodzielnym stanowisku prawniczym/, głównie spośród b. sędziów sądów wojewódzkich i okręgowych sądów pracy i ubezpieczeń społecznych oraz b. pracowników administracji. Część kadry pracowała uprzednio w organach prokuratury, w placówkach naukowych, oraz na stanowiskach radców prawnych.

43 sędziów należy do PZPR /70,5\%/, 4 do SD /6,6\%/, 3 do ZSL /4,9\%/, 11 jest bezpartyjnych /18\%/. Zarówno w NSA w Warszawie,

- 11 -

jak i w ośrodkach zamiejscowych istnieją podstawowe organizacje partyjne PZPR, z tym że w niektórych ośrodkach - ze względu na małą liczbę członków - wspólnie z innymi instytucjami prawniczymi / we Wrocławiu z Okręgową Komisją Arbitrażową, w Lublinie - z Okręgowym Sądem Pracy i Ubezpieczeń Społecznych/. Należy podkreślić, że przez cały okres istnienia NSA w sądzie tym nie powstały żadne związki zawodowe.

Wielu sędziów zaangażowanych jest w różnego rodzaju działalność społeczną m.in. jako członkowie różnych komisji w komitetach wojewódzkich PZPR; w instancjach ZSL i SD oraz w WRN ${ }^{21}$.

IV. W Państwowym Arbitrażu Gospodarczym zatrudnionych jest 341 arbitrów, w tym 65 - w Głównej i 276 w okręgowych komisjach arbitrażowych.

Około 40\% arbitrów stanowią członkowie Partii. Organizacje partyjne działające w Arbitrażu potrafiły skutecznie integrować ogół pracowników wokół realizacji zadań ustawowych tej instytucji. W trudnych latach 1980-1981 pracownicy Arbitrażu wykazali właściwą postawę ideowo-polityczną, zgodną z kierunkami polityki partii i podstawowymi interesami państwa.

Kadra pracowników zatrudnionych w Państwowym Arbitrażu Gospodarczym wyróżniła się pogłębioną znajomością funkcjonowania gospodarki narodowej oraz mechanizmów i instrumentów ekonomicznych mających

21 Wojewódzkie Rady Narodowe - terenowe organy władzy w PRL na szczeblu wojewódzkim. 
na względzie zapewnienie zgodności umów zawieranych w obrocie gospodarczym z celami narodowych planów społeczno-gospodarczych. Stąd w orzecznictwie Państwowego Arbitrażu Gospodarczego znajduje odzwierciedlenie ochrona nie tylko praw podmiotowych przedsiębiorstw, lecz także interesu ogólnospołecznego. Podkreślenia wymaga fakt, że od czasu wejścia w życie nowych podstaw prawnych funkcjonowania gospodarki - orzecznictwo arbitrażowe włączyło się w sposób zdecydowany w utrwalanie w praktyce zasady reformy gospodarczej.

V. W 397 zespołach adwokackich wykonuje zwód 3.304 adwokatów na ogólną liczbę 5.608 osób wpisanych na listę adwokatów.

Okres po sierpniu 1980 r. przyniósł niekorzystne zmiany w tym środowisku. Szeregi PZPR opuściło 168 osób; ponadto 3 adwokatów odeszło z SD, a 4 - z ZSL. Obecnie członkami PZPR jest 731 adwokatów

/tj. 22\% ogółu wykonujących zawód/, 192 - SD /6\%/ i 144 /4\%/ - ZSL. Szereg adwokatów reprezentowało negatywne postawy polityczne, utrzymywało ścisłe kontakty z b. KSS-KOR ${ }^{22}$, KPN, Komitetami Obrony Więzionych za przekonania i ośrodkami dywersji antypolskiej. Wprowadzenie stanu wojennego częściowo zahamowało negatywne trendy w tym środowisku. Część adwokatów zaniechała czynnej negacji działań władzy na rzecz normalizacji życia w kraju, ale niektórzy zwiększyli aktywność w kierunku sprzecznym z interesami socjalistycznego państwa. M.in. ukształtowała się nieformalna grupa tzw. obrońców politycznych, sale sądowe nierzadko były wykorzystywane do demagogicznego głoszenia haseł mających na celu dyskredytowanie PZPR i władz państwowych, niektórzy adwokaci współuczestniczyli w wypracowywaniu taktyki działania dla nielegalnych struktur podziemnych. Postawy takie spotkały się z daleko idącym liberalizmem organów samorządu adwokackiego.

Przeprowadzona w 1983 r. kampania sprawozdawczo-wyborcza w adwokaturze przyniosła straty członkom partii. Częste były negatywne politycznie wystąpienia, głównie ze strony osób od lat znanych z antypaństwowej działalności. M.in. żądano powszechnej amnestii dla więźniów politycznych, wprowadzenia statusu więźnia politycznego, reaktywowania b. Polskiego Stowarzyszenia Penitencjarnego oraz Stowarzyszenia Adwokatów i Aplikantów Adwokackich. Powszechnej krytyce poddawane zawarte w ustawie o adwokaturze regulacje dotyczące uprawnień Ministra Sprawiedliwości i ograniczeń wiekowych w wykonywaniu zawodu; w tym zakresie były liczne postulaty nowelizacji ustawy. Szczególnie negatywny był przebieg walnego zgromadzenia w Warszawie w dniach 3-4 września 1983 r.

22 Komitet Samoobrony Społecznej - Komitet Obrony Robotników - następca Komitetu Obrony Robotników, organizacji opozycyjnej powstałej 23 września $1976 \mathrm{r}$. 
Obok negatywnych wystąpień w trakcie tego zgromadzenia podkreślenia wymaga fakt, że wśród 67 wybranych delegatów na Krajowy Zjazd Adwokatury znalazło się 36 osób reprezentujących wrogie postawy polityczne.

Krajowy Zjazd Adwokatury w dniach 1-3 października 1983 r. został zdominowany przez grupę opozycyjną, która wystąpiła w sposób zorganizowany pozyskując większość adwokatów biernych. Rezultatem takiej atmosfery Zjazdu były wyniki wyborów do centralnych organów samorządu adwokackiego oraz treści podjętych uchwał i wniosków o negatywnym wydźwięku społeczno-propagandowym.

Przebieg Zjazdu determinowany był wysiłkami kampanii sprawozdawczo-wyborczej w okręgowych izbach adwokackich, w wyniku której wśród 315 delegatów było 55 członków PZPR, 24 - SD i 12 - ZSL /na Zjeździe w 1981 r. na 460 delegatów odpowiednio: 117, 39 i 29/. Około 1/3 składu delegatów stanowiły osoby, których dotychczasowa działalność i prezentowane postawy polityczne wymierzone są przeciwko socjalistycznemu porządkowi prawnemu. Wśród nich znajdowało się m.in. 4 b. doradców KKP NSZZ „Solidarność”, 12 internowanych w okresie stanu wojennego i 83 osoby jawnie wspierające $b$. NSZZ "Solidarność" lub mające ścisłe powiązania $\mathrm{z}$ hierarchią kościelną.

Nowo wybrane władze adwokatury nie podjęły znaczących działań na rzecz zneutralizowania negatywnych zjawisk i wsparcia pozytywnych procesów w środowisku. Nadal podejmowane są działania na rzecz podtrzymania elitarności zawodu, ograniczania dostępu młodzieży pochodzenia robotniczo-chłopskiego do adwokatury, uzyskania nieograniczonej autonomii oraz nowelizacji ustawy celem wyeliminowania ograniczeń wiekowych w wykonywaniu zawodu i uprawnień Ministra Sprawiedliwości wobec samorządu. Niepokojącym zjawiskiem są również próby przyjmowania do adwokatury osób powszechnie znanych w środowiskach prawniczych z działalności antysocjalistycznej /m.in. w bydgoskim, łódzkim, szczecińskim, radomskim, wałbrzyskim, płockim, krakowskim, zielonogórskim i w Warszawie/. Ograniczenie negatywnych rezultatów Krajowego Zjazdu i poprawy sytuacji $\mathrm{w}$ adwokaturze wymaga wzmożenia pracy politycznej w środowisku oraz podjęcia działań dyscyplinujących m.in. przez organy finansowe i ZUS ${ }^{23}$. Występuje rażąca rozbieżność pomiędzy dochodami deklarowanymi a faktycznie utrzymywanym standardem życiowym znacznej części adwokatów.

Aresztowanie adw. Macieja Bednarkiewicza i ujawnienie jego działalności kryminalnej wywołało znaczny rezonans w środowisku m.in. organy samorządowe w Warszawie, Gdańsku i Krakowie skutecznie neutralizowa-

23 Zakład Ubezpieczeń Społecznych. 
ły próby podejmowania akcji petycyjnych, stwierdzono dziwny wzrost dochodów wykazywanych w zespołach, stwierdza się izolowanie niektórych inspiratorów dotychczasowych działań opozycyjnych /np. J. Olszewskiego, Wł. Siła-Nowickiego, E. Wendego/.

\section{-14 -}

VI. Na liście radców prawnych wpisanych jest 13.655 osób, z których ponad 12 tysięcy wykonuje zawód. Ponadto w okręgowych komisjach arbitrażowych szkoli się 938 aplikantów radcowskich.

Uchwalona 6 lipca 1982 r. ustawa o radcach prawnych stworzyła warunki zapewniające umacnianie praworządności w systemie gwarancji przestrzegania prawa $\mathrm{w}$ działalności państwowych jednostek organizacyjnych, organizacji spółdzielczych i innych jednostek uspołecznionych. Wprowadziła bowiem rozwiązania, które optymalnie mają zapewnić przestrzeganie prawa w działalności wszystkich jednostek organizacyjnych w państwie oraz nadała radcom prawnym odpowiednią do ich zadań rangę zawodową i społeczną.

Dotychczas środowisko radców prawnych nie jest jeszcze zintegrowane, czemu sprzyja specyfika tego zawodu - m.in. wykonywanie pracy w odosobnieniu oraz odrębność zakresów prawnego zainteresowania charakterystyczne dla danej jednostki organizacyjnej. Nie stwierdza się zagrożeń politycznych w tym środowisku, a wpływy partii są znaczne. W dniach 24-25 września 1983 r. odbył się I Krajowy Zjazd Radców Prawnych, którego przebieg i wyniki były pozytywne. Wśród 51 wybranych członków Krajowej Rady Radców Prawnych jest 17 członków PZPR, 4 - ZSL i 1 - SD. Dotychczasowa działalność organów samorządowych radców prawnych sprzyja realizowaniu ustawowych zadań przez to środowisko.

Z przeprowadzonych badań ankietowych wynika, że wysokość zarobków uzyskiwanych przez radców prawnych w zestawieniu ze stosunkowo luźnym powiązaniem z zakładem pracy czyni ten zawód atrakcyjnym i w związku z tym obserwuje się tendencję przechodzenia do niego prawników z innych zwodów. Zjawisko to oddziaływuje negatywnie na zapewnienie stabilizacji kadrowej $\mathrm{w}$ innych zawodach prawniczych, zwłaszcza w prokuraturach i sądach oraz wywołuje też niekiedy krytykę społeczną co do słuszności przyjętych regulacji prawnych dających radcom prawnym większe przywileje niż pozostałym prawnikom uspołecznionych jednostek organizacyjnych.

$$
x \quad x \quad x
$$

W świetle przedstawionej sytuacji społeczno-politycznej w poszczególnych środowiskach prawniczych występuje szereg zjawisk, które

wymagają podjęcia działań na rzecz ich wyeliminowania lub ograniczenia. W szczególności konieczna jest realizacja następujących przedsięwzięć: 
1. Wydział Administracyjny KC PZPR wspólnie z egzekutywami POP w Ministerstwie Sprawiedliwości, Prokuraturze Generalnej, Sądzie Najwyższym i Naczelnym Sądzie Administracyjnym opracują harmonogram działań zmierzających do wzmożenia pracy ideowo-politycznej w swych środowiskach. Program winien przewidywać działania zmierzające do wyeliminowania wpływów opozycji w środowisku i przyciągnięcia wahających się do aktywnego poparcia aktualnej linii partii i rządu.

2. Kierownictwo Ministerstwa Sprawiedliwości i Prokuratury Generalnej we współdziałaniu z POP opracują harmonogram czynności zmierzających do ich wyeliminowania występujących problemów i nieprawidłowości do końca marca $1984 \mathrm{r}$.

3. Zaostrzenia wymaga represja karna przede wszystkim za przestępstwa o charakterze politycznym, zagarnięcia mienia społecznego znacznej wartości, niegospodarności i marnotrawstwa, łapownictwa, zgwałceń i kradzieży z włamaniem. W znacznie większym stopniu w orzecznictwie sądowym wykorzystywane być powinny możliwości represji ekonomicznej oraz wymierzane kary dodatkowe - zwłaszcza zakaz zajmowania stanowisk, wykonywania zawodu lub prowadzenia określonej działalności i podawania wyników do publicznej wiadomości.

4. Zgodnie z zaleceniami B.P. z 1982 r. dalszego usprawnienia wymaga system naboru i kształcenia kadr do sądownictwa i prokuratury. Uzupełniające propozycje $\mathrm{w}$ tej sprawie - opracują Wydział Nauki i Oświaty i Wydział Administracyjny KC PZPR oraz Ministerstwo Nauki, Szkolnictwa Wyższego i Techniki.

5. Wydział Administracyjny KC PZPR w porozumieniu z Ministerstwem Sprawiedliwości i Prokuraturą Generalną zorganizuje dwudniowe kursy dla I sekretarzy POP z sądów i prokuratur wojewódzkich dla omówienia węzłowych problemów pracy organizacji partyjnych w sądach i prokuraturach. Pierwszy kurs odbył się w m-cu lutym br.

\section{-16 -}

Kolejne spotkanie przewiduje się w kwietniu br. Dla omówienia zadań organów ścigania i wymiaru sprawiedliwości wynikających z decyzji Krajowej Konferencji Delegatów.

6. Komitety wojewódzkie PZPR podejmą działania na rzecz aktywizacji podstawowych organizacji partyjnych i członków PZPR działających w adwokaturze w kierunku ograniczenia wpływów osób reprezentujących postawy opozycyjne oraz rozważą celowość spowodowania kontroli wybranych zespołów adwokackich i adwokatów przez organy finansowe i ZUS /Pierwsze kontrole już są prowadzone/. 
7. Potrzeba zapewnienia wszystkim uspołecznionym jednostkom organizacyjnym pełnej obsługi prawnej wymaga doprowadzenia do realizacji zasady zatrudnienia się radców prawnych w jednym zakładzie pracy na pełnym etacie. W tym celu planuje się m.in. zwiększyć liczbę szkolonych aplikantów radcowskich w okręgach odczuwających niedobór radców prawnych.

8. Celowym byłoby przyspieszenie wydania ustawy o Sądzie Najwyższym. Przyspieszone winny być prace legislacyjne nad projektami ustaw o Prokuraturze PRL.

9. Wymaga przyspieszenia decyzja w sprawie podwyżek płac dla prokuratorów i sędziów celem zahamowania odpływu doświad czonych i sprawdzonych pracowników oraz zagwarantowania dopływu wartościowej kadry.

10. Szczegółowo zbadać fakty niewłaściwych postaw pracowników wymiaru sprawiedliwości i prokuratury, a w wypadku potwierdzenia podjąć właściwe decyzje eliminujące fakty kompromitujące te organa i osoby niedające rękojmi właściwego wykonywania zawodu.

Wydział Administracyjny KC PZPR

Warszawa, luty $1984 \mathrm{r}$.

Oryginał, maszynopis.

Archiwum Akt Nowych, zespół akt: Polska Zjednoczona Partia Robotnicza. Komitet Centralny w Warszawie, sygn. V/222, k. 163-178. 